Open Access

\title{
A new approach to social inequality: inequality of income and wealth in South Korea
}

Kwang-Yeong Shine

Correspondence: kyshin@cau.ac.kr Department of Sociology, Chung-Ang University, 84 Heukseok-ro Dongjak-gu, Seoul, Korea

\begin{abstract}
This paper attempts to provide a new approach to social inequality, focusing on income and wealth inequality and the relationship between income inequality and wealth inequality. With an analysis of the data linking survey data with administrative data in South Korea, this paper reports that wealth, employment status, family size, and education are significant contributors to income inequality. However, income and loans are the two most significant factors contributing to wealth inequality. Income derived from economic activity and loans based on the leverage in the financial market have exacerbated wealth inequality as higher income groups tend to utilize more loans in the financialized economy, widening the gap between the rich and the poor. Wealth inequality has different dynamics from income inequality, mediated through leverage in South Korea.
\end{abstract}

Keywords: Income inequality, Wealth inequality, Regression-based inequality decompostion, Administrative data, South Korea

\section{Introduction}

This paper attempts to explore income inequality and wealth inequality and their relationship, revealing that the two main indicators of inequality have different dynamics of making economic inequality in contemporary South Korea. Analyzing the linked data of the Survey of Household Finance and Living Conditions (SHFLC) collected by the Statistical Office with the administrative data on household income by the National Tax Office in South Korea, this paper identifies contributing factors to household income inequality and wealth inequality. It also shows that the traditional approaches to social stratification have limitations to fully understand the issue of rising economic inequality in the post-industrial society characterized by the growing elderly population and the changing family system as well as the transformation of industrial production.

Economic inequality has become an important political issue as well as an academic issue worldwide in the twenty-first century (Piketty and Saez, 2003; Piketty, 2013; Atkinson, 2015; Stiglitz, 2012). Sociologists have not been successful in explaining the rise of income inequality. Piketty has shown how income and wealth have been

(c) The Author(s). 2020 Open Access This article is licensed under a Creative Commons Attribution 4.0 International License, which permits use, sharing, adaptation, distribution and reproduction in any medium or format, as long as you give appropriate credit to the original author(s) and the source, provide a link to the Creative Commons licence, and indicate if changes were made. The images or other third party material in this article are included in the article's Creative Commons licence, unless indicated otherwise in a credit line to the material. If material is not included in the article's Creative Commons licence and your intended use is not permitted by statutory regulation or exceeds the permitted use, you will need to obtain permission directly from the copyright holder. To view a copy of this licence, visit http://creativecommons.org/licenses/by/4.0/. 
concentrated into top income groups in the advanced industrial democracies since the late twentieth century. As many sociologists have already argued, however, sociologists have not been successful in providing sociological explanations of the rising inequality (Western, 1999, Myles, 2003; Kenworthy, 2007; Savage and Burrows, 2007). While sociologists have been concerned with inequality of mobility chance or social fluidity between social groups such as social class, gender, and race, sociologists have not significantly contributed to an understanding of the rising income inequality and wealth inequality.

The traditional approach to social stratification has focused on individual work and occupation. The work-based approach to social inequality has been a core of social stratification and class analysis in sociology. It has formed a research paradigm in social stratification which focuses on the role of education mediating the relationship between family background and individual occupation (see Blau and Duncan, 1965; Breen and Muller, 2020; Erikson and Goldthorpe, 2000; Featherman and Hauser, 1975; Hout and DiPrite, 2006; OECD, 2018). Occupation has played a key role as an origin (father's occupation) and destination (children's occupation) in the social mobility research, while education has worked as a social elevator for upward social; mobility over generations. Thus, the OED model has been the core research framework in social stratification for the past decades, called "a disciplinary default" (Savage, 2016).

There have been good reasons why sociologists have focused on occupation rather than income and wealth. There have been practical reasons for occupation rather than income as a key area on research on social stratification. In practice, measurement error is serious in getting information about income and wealth. For example, many respondents do not know their income exactly, or they do not want to tell their income to others. Therefore, almost all survey questionnaires asked income in an interval scale with the open-ended top income, making a precise measurement of income inequality impossible.

Sociologists have been preoccupied with the working population, excluding the elderly mostly out of the labor forces. The majority of the elderly population who are not working has been excluded from the research on social stratification. In the past, women were excluded in the social stratification research until the 1970s, whereas the elderly were excluded in the social stratification research in the late twentieth century (for the case of women, see Acker, 1973). Much of the research on social mobility and sex segregation of jobs has focused on the working population.

Sociologists have assumed individuals as a unit of analysis of social stratification, while they have conceived family background as an essential factor to shape children's education and occupation. Household as a social institution of pooling family member's income has not been emphasized. Educational investment in children's education has been made by family or household level, not an individual level. Family or household is a unit of family consumption, children's education, and daily social life.

Finally, most of the research on social stratification has not paid attention to wealth inequality, while wealth inequality is much more severe than any other dimension of inequality in almost all countries (Alvaredo et al., 2018; Therborn, 2013; Piketty, 2013). Some magazines, such as Forbes, report the global rich with narratives of the success story of the people in business (Kroll and Dolan, 2019). But there has been little research in sociology on how wealth is associated with social stratification and inequality. 
Research on the labor market and gender has focused on wage disparity among the employees. Owners of capital, such as stockholders or building owners, get a much higher income than the earnings of employees, though some do not have jobs and occupations.

This paper investigates two dimensions of inequality, income inequality and wealth inequality, and examines the relationship between the two by using linked administrative and survey data. In the next section, we will discuss the relationship between income and wealth and explore the relationship between wealth and income inequality. In the third section, we will explain the Survey of Household Finance and Living Conditions (SHFLC) and the linking of survey data to administrative data from different governmental agencies to get accurate information about income. Then, we will briefly explain the regression-based-inequality decomposition method used in the statistical analysis. The fourth section reports the results of an empirical analysis, identifying major contributing factors to income inequality and wealth inequality. In the last section, some implications of the finding of this research will be addressed concerning research on social stratification.

\section{Household income and wealth}

Recently, income has been a focal point of discourse on inequality. While income has been considered as a primary dimension of economic inequality in social sciences, income has seldom been the main topic of theoretical discourse or a subject of empirical research in sociology. Research on inequality and stratification has paid more attention to structural or institutional factors that are assumed to generate socio-economic inequality that we observe every day. For example, status attainment approaches have focused on the relationship among social origins (parents' occupation), education (respondents' education), and destination (respondents' occupations) called the OED model. However, the relationship between occupation and income has not been fully elaborated. The only average of earnings of occupation has been assumed to represent the income level of each occupation without recognizing that the variation of an individual's earnings has been affected by other factors than occupation, such as industry, firm size, employment status, and gender.

Individual occupation has been considered as a proxy of socioeconomic status or social stratification in sociology. Does an individual's occupation represent one's economic wellbeing? Does it affect the distribution of household income that influences family expenditure and educational investment for children? The answer is yes, but only partially true. With an increasing diversification and flexibility in the labor market, there have been increasing numbers of non-standard workers who get less paid by employers, less secured by unions, and less protected by the state (Kalleberg, 2000; OECD, 2019; Shin, 2013). The rise of precarious work challenges the validity of occupation as a cornerstone of earning inequality.

Earnings refer to economic rewards from work, and there are many other economic gains from other than work. Income refers to a flow of money that includes not only economic rewards from work but also economic gains from factors such as capital, land, and pension and entitlement. Thus, it has a variety of forms, such as wage, public transfer, profits, rent, interest, and dividends. As the capitalist economy develops and employment relation becomes a dominant form of the economic system, the majority 
of the people receive wage or salary in exchange for their work as employees. Those who hire others in their business get profits. Thus wage or salary comes from a part of the profits gained by employers.

However, new forms of income are derived from non-producing capital. Nowadays, as the financial sector dominates the economy and everyday life, more people tend to own stocks and bonds to get more economic benefits. Those who own stocks and bonds get capital gains through a transaction of them in the stock market or a dividend given to stockholders by a corporation. Financialization of the economy leads to the increasing importance of the financial sector in the economy relative to the economy, and the growing number of people engages in the financial market and gets income from financial capital (Davis and Kim, 2015). The ascendancy of the financial sector has led to the new rules of accumulation without producing material goods, enabling middle-class members to engage in the stock market transaction and real estate markets for short-term profits. With the digitalization of the daily trading of stocks at home, "profits without producing" has been possible for middle-class households as well as the global financial investors (Sawyer, 2013). Financialization has completely transformed the distribution of income and wealth through the mediation of financial institutions such as investment banks and financial firms specialized in real estate speculation. At the household level, households utilizing credit systems begin to use leverage to purchase an asset, mostly housings and stocks, with the expectation of the increasing return of investment. In particular, the rising housing price in many countries has instigated middle-class households and wealthy investors to use debt financing or bank loans to invest in the housing market and real estate markets. Increasing household debt has been observed in several countries where housing bubbles were made, generating high household indebtedness ratio. South Korea displays a very high level of household indebtedness and debt-to-total asset ratio among OECD countries (OECD, 2020). ${ }^{1}$

Income is determined by the monthly economic gains derived from economic activities or profits from investment or rent, including houses or offices. In this case, for the majority of the people, one's occupation or social class is an essential factor in explaining an individual's income. However, substantial social changes that occurred in the late twentieth century challenged the long tradition of approach to income inequality. The first challenge is that an individual's income may be quite different from household income because the growing number of married couples jointly participates in the labor force (Esping-Andersen, 1999: ch. 4). Thus, household income is a pooled income of individual household members when more than one family member engaged in economic activity. The growth of dual-earner family contributes to the divergence of household income from individual income in the labor market in post-industrial societies.

Household income is also affected by the development of welfare programs to cope with social problems such as poverty and unemployment. An effect of the development of the welfare state has been an increase of public transfer to the people with low income or unemployment. Also, the rise of the aged population retired from the labor market also increases the proportion of the people who receive pension or benefits not

${ }^{1}$ In South Korea, the household debt level was $184.20 \%$ of the net household disposable income in 2018, which was more than twice that of Germany and Japan. It was $147.53 \%$ in 2010. See OECD (2020) for the details. 
associated with work. The growth of the population getting pension benefits contributes to the growing impact of public transfer in income distribution. The impacts of welfare programs on income distribution have been associated with the level of public social expenditure and tax rate. On average, OECD countries reduce more than onequarter of market income inequality via tax and cash transfers. Korea was one of the least redistributive countries in the OECD, with less than a $10 \%$ decrease in the Gini index of income inequality in 2014 (OECD, 2020).

Wealth is a stock of valuable assets, including a share of stocks of companies, savings in banks, the ownership of property, insurance schemes, pension, and luxury goods. Some form of wealth, such as a house or a car, is visible, whereas other forms of wealth, such as ownership of stocks and insurance, are entirely invisible to outsiders. As some wealth such as savings, lands, or estates themselves generate income, "a disproportionate share of the highest income comes from wealth" (Davis, 2019: 128). Besides, parts of wealth itself are convertible to market income by selling stocks and houses.

Wealth can function as a private safety net in case of unemployment, severe illness, divorce, industrial injury industry, and retirement. In particular, housing ownership plays a role as a social safety net against the various social risks in one's life in countries where social welfare is not sufficiently institutionalized. Housing ownership can be a functional equivalence to social welfare in South Korea. Thus, the ratio of housing ownership has increased even after the income has decreased in their 60s. When earners decease, of course, the earned income disappears. But, the wealth of the deceased is inheritable to children. Thus, wealth inequality is much more stable than income inequality over time.

Then, how is wealth formed? There are many pathways through which wealth is formed and wealth inequality is generating. The typical pathway is the accumulation of some part of disposable income as savings for a period at an individual level or the household level. Thus, the surplus income, that is, income minus expenditure, are kept in banks or invested in the stock market or real estate markets. The formation of a financial asset can be a stock of saved income. Higher-income earners tend to save a more substantial part of their income. Those who have their own housings can save more than renters of housings. For example, in South Korea, the top 10\% of income group has 22.39 times higher savings than the lowest 10\% of income groups in 2017.

The second pathway is the rise of values of possessed wealth, such as ownership of capital, houses, or other property. Thomas Piketty (2013) argues that the dynamics of increasing wealth inequality is simply based on the fact that the rate of return on capital $r$ is greater than the rate of return to labor $g(r>g)$. Also, financial assets and real estate multiply itself through capital value change. The rise in the price of real estate, stocks, and bonds also contributed to the growth of wealth for renters. In addition, the rise in rent also played a vital role in the growth of wealth. Wealth has been more severely affected by market fluctuation than income. Sometimes, the asset bubble bursts out when the asset-inflated price exceeds the intrinsic value of the asset.

The third pathway is the role of wealth as leverage of loans. Wealth can function as collateral for borrowing loans from banks. Financial organizations utilize a credit system to reduce the risk of bad credit. Even speculative mortgage loans have been possible for new investment in the financial market. Thus, profits without producing real values dominate the global economy in recent years. The wealthy people can utilize the 
loans to invest in the stock market and the financial market. Therefore, credit inequality becomes a new type of inequality emerging in the period of financialization. While debt-to-equity ratios increased on average, wealthy people utilize financial resources easier than the poor in new investments.

The fourth pathway is the transmission of parents' wealth to children through private transfer or inheritance after parents' death. Thus, the family's wealth has contributed to the wealth formation of descendants over generations. Children of the rich family acquire the properties of their parents after or before their parents pass away. The impact of inheritance of wealth on wealth inequality depends on the inheritance tax rate and the number of heirs in each country. Persistent wealth inequality and the stability of wealthy people have been common across countries. In short, economic inequality is largely ameliorated by the unequal ownership of income-producing assets and rent saving property.

\section{Data and method}

\section{Data and variables}

In this paper, we used the data of the Survey of the Household Finance and Living Conditions (SHFLC), which is the linked data of the survey data and administrative data. The SHFLC has been collected by the Statistical Office in South Korea since 2010. The Statistical Office of South Korea began to collect information about household income, debt, wealth, and welfare to know the dynamics of finance after the global financial crisis in 2008-2009. The sample size was 10,000 cases until 2011, and after that, it increased to 20,000 households since 2012. The SHFLC has been replaced by $20 \%$ of the total sample every year. Thus the SHFLC will be utterly new after 5 years.

In this paper, we used SHFLC 2017 with the sample size 18,497 in 2017. The Statistical Office in South Korea began to link the SHFLC with the administrative data to overcome shortcomings of the survey data on income. Linking survey data with registered administrative data provides a new research possibility on inequality research with more accurate information on personal and household income. Administrative registered data in the SHFLC included the various data source to measure household income: the annual income and tax from the National Tax Office, the transfer income and pension from the Social Insurance Office, the health insurance and health service information from the National Health Insurance, educational allowance from the Ministry of Education, and child allowance from the Ministry of Health and Welfare.

Table 1 reports different measures of inequality of income and wealth in the survey data and the linked data in 2017. As we expected, the linked data displays a higher maximum income than the survey data, revealing that the survey data underreport the income of the top income. It also shows that the survey data do not accurately identify the income of the low-income groups since the median shifts from 3698 to 3966 . As a result, Gini coefficients measured by the linked data, 0.4416 , is higher by $4.25 \%$ than that of the survey data, $0.4236 .^{2}$ The linked data that uses income from the

\footnotetext{
${ }^{2}$ The Gini coefficient in the SHFLC 2017 is much larger than the Gini coefficient reported to the OECD by the Statistical Office Korea. The Gini coefficient reported to the OECD is based on the Household Income and Expenditure Survey (HIES) with a smaller sample size than the SHFLC. Instead of the HIES, the Statistical Office Korea began to report the statistical indicators of income distribution from the SHFLC since 2015. For example, the Gini coefficient in 2017 was 0.355 , whereas it was .307 in 2012 . The difference mainly came from the data with sample size.
} 
Table 1 Measurement of income inequality and wealth inequality, 2017

\begin{tabular}{lll}
\hline & Survey data & Linked data \\
\hline Income & 3,698 & 3,966 \\
Median & 102,400 & 161,310 \\
Maximum & .4236 & .4416 \\
Gini coefficient & .2883 & .3165 \\
Share by top 10\% & .4598 & .4901 \\
Share by top 20\% & 12.5800 & 12.3469 \\
p90/p10 & 2.4542 & 2.6421 \\
Palma ratio & & \\
Wealth & 21,482 & 21,482 \\
Median & $2,670,220$ & $2,670,220$ \\
Maximum & .5738 & .5738 \\
Gini coefficient & .4389 & .4389 \\
Share by top 10\% & .6147 & .6147 \\
Share by top 20\% & 55.6727 & 55.6727 \\
p90/p10 & 7.2046 & 7.2046 \\
Palma ratio & which is equven \\
\hline
\end{tabular}

Note: The unit of income and wealth is 10 thousand Won, which is equivalent to roughly 9 US Dollars. The linked data use information about income from the tax agency, but it uses information about wealth from the survey data

administrative record shows the fact that the survey data collected by the Statistical Office in South Korea tend to underestimate the level of the top income and the degree of inequality of the household income. The concentration of income on the top $10 \%$ and top $20 \%$ of income groups also increases from 0.2883 in the survey data to 0.3165 in the linked data. The share by the top $10 \%$ and the top $20 \%$ also show a similar pattern of the rising concentration of income. However, p90/p10, which indicates the income gap between the income of the lowest $10 \%$ and the highest $10 \%$ income group, shows a slightly different pattern, by reducing the ratio by $1.85 \%$. On the contrary, the gap between the poor $40 \%$ and the richest $10 \%$ widen when the linked data is used. The Palma ratio, the ratio of the richest $10 \%$ of the households' share of income divided by the poorest $40 \%$, shows an increase from 2.4542 to 2.6421 .

Wealth inequality is much higher than income inequality across the whole country (Sierminska, Smeeding, and Allegrezza, 2013; Jäntti, Sierminska, and Kerm, 2013). On average, the popular perception of the rising inequality has been derived by not only income inequality but also wealth inequality. Wealthy persons consume luxury goods and cars and live expensive housings in gated communities. Also, the increasing housing price contributes to the perception of wealth inequality as well as wealth inequality itself. In South Korea, the rising housing price in recent years has contributed to the fear of the youth of the middle class and the working class, as housing ownership was very low among young adults (see Fig. 1). The Korean youth has shown the lowering marriage rate and birth rate of the married couple mainly due to the housing shortage and housing bubbles over the decades as well as the high rate of unemployment (Kim, 2017).

In this paper, income is measured by annual household income containing the market income and public transfer income. The market income includes earnings from work, profits from business, property income such as interests or rents, and the private 


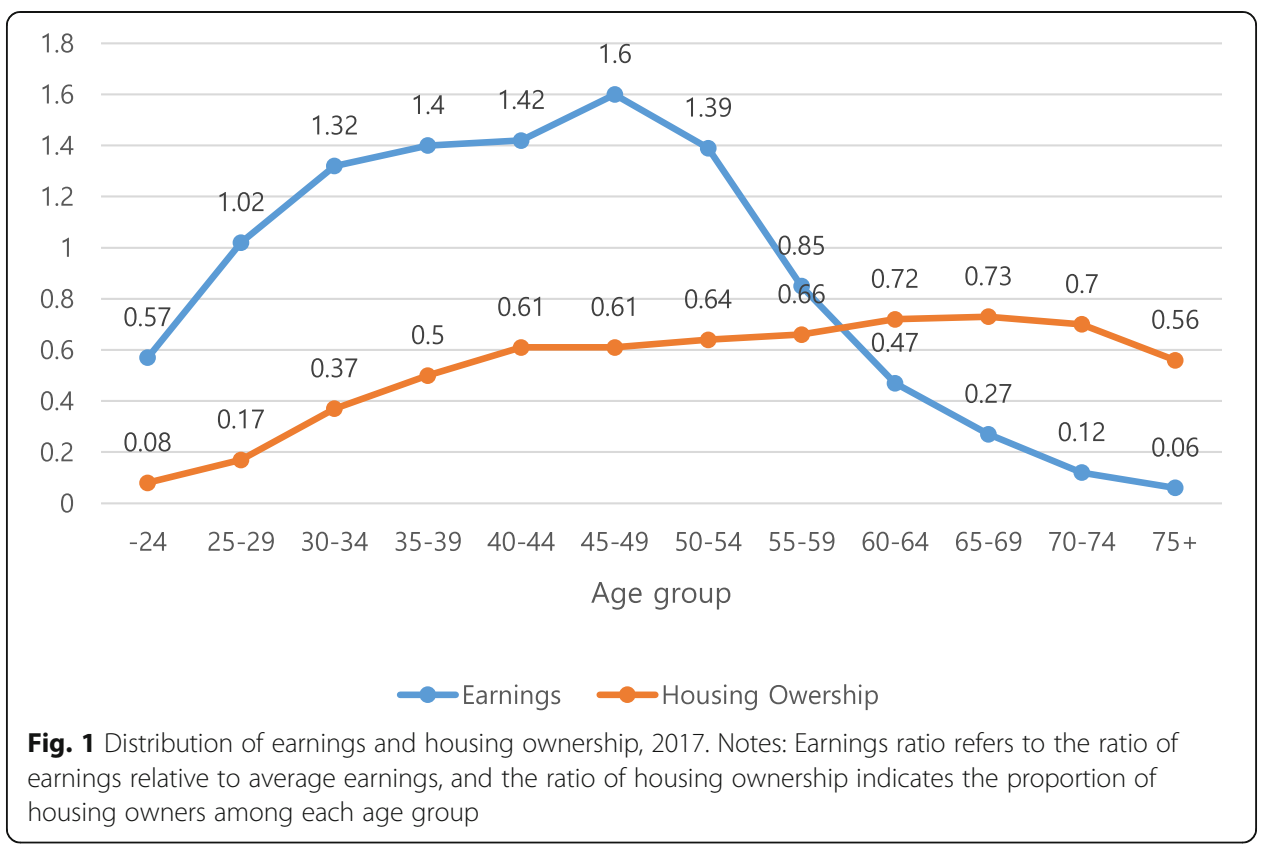

transfer. Pre-tax income will be used in the following to focus on the impacts of contributors to before-tax income inequality. Wealth is measured by the price of a variety of possession, including properties such as houses, lands, buildings, and cars. Linking the survey data with the administrative data provides more accurate data on income and wealth than any other data set in South Korea.

The joint distribution of income and wealth shows highly polarized distribution, characterized by the two poles around income poor-wealth poor and income rich-wealth rich. Figure 2 displays a topographic picture of the joint distribution of income and wealth in 2017. We can see that the lowest $5 \%$ income and wealth group displays one pole with 3.56 times higher proportion than the average. The highest $5 \%$ of income and wealth shows 7.19 times higher proportion than the average. The lowest $10 \%$ and the

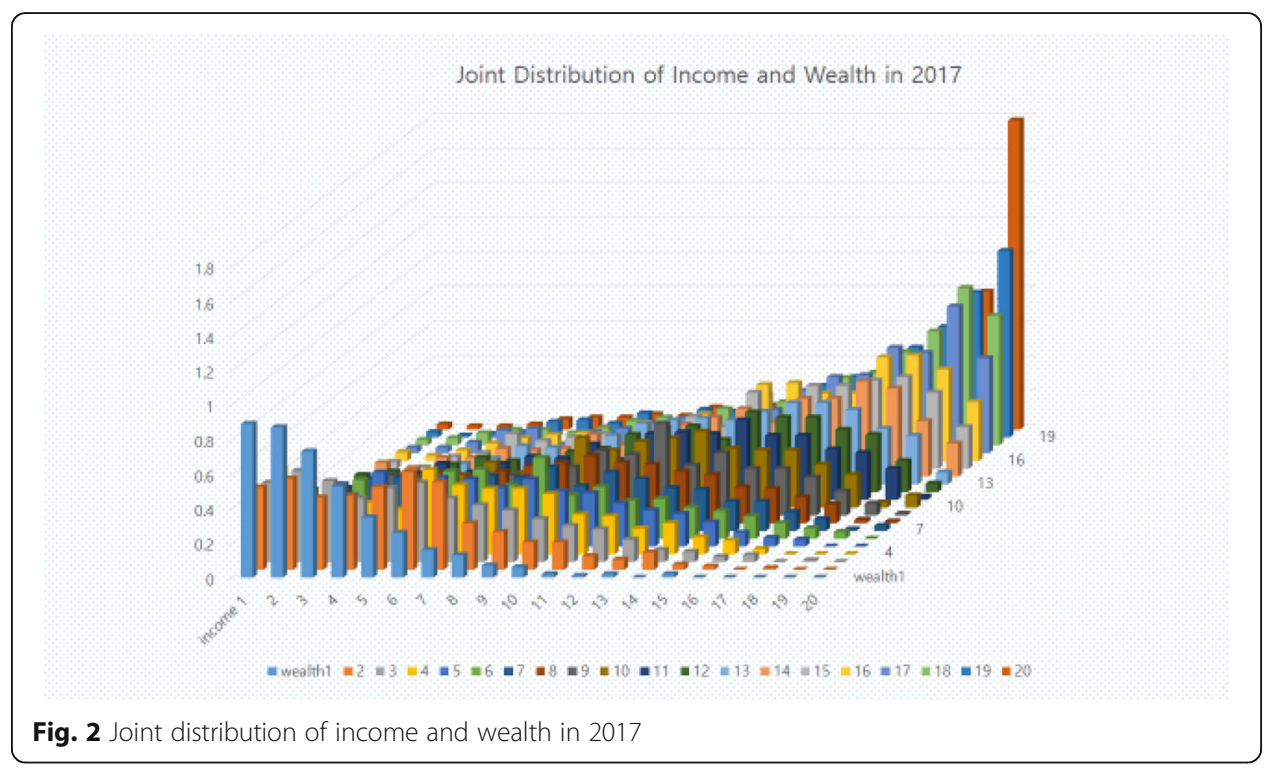


highest $10 \%$ in both income and wealth distribution show the second-highest density. However, in the middle of income and wealth distribution in Fig. 2, there is more frequent mobility than any other parts of the joint distribution of income and wealth. It shows that there is a low level of association between income and wealth in the middle of income group and in the middle wealth group. High income and high wealth clusters are formed in the poles.

Table 2 reports the summary of the description of major independent variables. Those are mostly the characteristics of the head of households except family size. Thus, sex in the SHFLC refers to the sex of the household head. The majority of the household head is male (75.51\%), relative to females $(24.49 \%)$ in South Korea. The measurement of education is done by the calculation of years of education rather than categories based on the level of education. Family size refers to the number of family members. In the subsequent analysis, family size is categorized from one to six since there is a non-linear relationship between family size and income. Occupation includes non-working people as well as the working population since it deals with the entire household. Employment status also includes the category of non-working people.

Table 2 Descriptive summary of major variables $(N=18,497)$

\begin{tabular}{|c|c|c|c|}
\hline Variables & Explanation & Percent & Standard deviation \\
\hline$\overline{\log Y}$ & Log of annual income & 8.4173 & 0.9841 \\
\hline $\log W$ & Log of wealth & 9.5869 & 1.7747 \\
\hline \multirow[t]{2}{*}{ Sex } & $0=$ male & $75.51 \%$ & \\
\hline & $1=$ female & $24.49 \%$ & \\
\hline Age & Average & 55.2066 & 14.8992 \\
\hline Education & Years of completed education & 11.0702 & 4.7102 \\
\hline \multirow[t]{11}{*}{ Occupation } & Managers & $2.42 \%$ & \\
\hline & Professionals & $13.13 \%$ & \\
\hline & Clerics & $12.32 \%$ & \\
\hline & Service & $6.38 \%$ & \\
\hline & Sales & $7.85 \%$ & \\
\hline & Peasant & $5.11 \%$ & \\
\hline & Skilled workers & $9.42 \%$ & \\
\hline & Semi-skilled workers & $12.14 \%$ & \\
\hline & Unskilled workers & $10.29 \%$ & \\
\hline & Soldier & $0.28 \%$ & \\
\hline & Non-working & $20.64 \%$ & \\
\hline \multirow[t]{6}{*}{ Employment status } & Regular & $43.54 \%$ & \\
\hline & Non-regular & $11.78 \%$ & \\
\hline & Employer with employees & $5.50 \%$ & \\
\hline & Employer without employees & $17.48 \%$ & \\
\hline & Atypical workers & $1.02 \%$ & \\
\hline & Non-working & $20.67 \%$ & \\
\hline Family size & Average family members & 2.8413 & 1.2846 \\
\hline Elderly household & Age of household head $>65$ & $19.75 \%$ & \\
\hline Housing ownership & Owners of housing & $61.13 \%$ & \\
\hline
\end{tabular}

Note: The proportions of non-working are slightly different between occupation and employment status due to the collapse of family workers without pay to non-working in the distribution of employment status 
Soldiers in the occupational category are excluded in the following analysis because the market does not determine their incomes.

\section{Analytical methods}

To identify the extent to which some factors contribute to inequality of income and wealth, we use the regression-based inequality decomposition developed by Gary Fields (2003).

Assuming that the income is

$$
\ln y=X \beta+\varepsilon
$$

where $y$ is an $n \times 1$ vector of incomes; $X$ is an $n \times(K+1)$ matrix of individual and household characteristics (age, education, employment status, occupation, household size, etc.) including the constant; $\beta$ is a $(K+1) \times 1$ vector of coefficients, and $\varepsilon$ is an $n$ $\times 1$ vector of residuals. A sample of observations $\{\mathrm{yi}, \mathrm{xi}, i=1,2, \ldots n\}$ can be used to estimate the model.

The linear model (1) can be rewritten as:

$$
\begin{aligned}
& \ln y=\beta_{0}+\beta_{1} X_{1}+\beta_{2} X_{2} \ldots+\beta_{\mathrm{K}} X_{\mathrm{K}}+\varepsilon \\
& =\beta_{0}+Z_{1}+Z_{2} \ldots+Z_{\mathrm{K}}+\varepsilon
\end{aligned}
$$

where each $Z_{\mathrm{k}}$ is a "composite" variable, equal to the product of a regression coefficient and its variable $\left(Z_{\mathrm{k}}=\beta_{\mathrm{K}} X_{\mathrm{K}}\right)$, with $k=0,1, \ldots K$ and $X_{0}=1$.

For inequality decomposition calculations, the value of $\beta_{0}$ is irrelevant as it is constant for every observation.

The OLS estimate of (3) can be used for inequality decomposition:

$$
\ln \mathrm{y}=\mathrm{b}_{0}+\hat{b}_{1} X_{1}+\hat{b}_{2} X_{2} \cdots+\cdots+\hat{b}_{k} X_{k}+\hat{\epsilon}
$$

Marginal contribution of the $k$ th factor $\left(\hat{Z}_{k}=\widehat{b_{k}} X_{k}\right)$ to the variance of logarithm of income is as follows:

$$
\begin{aligned}
& S_{k}=\widehat{b_{k}} \operatorname{cov}(X k, \ln y) / \sigma^{2}(\ln y) \\
& \sum_{i=1}^{k} S_{k}=\sum_{i=1}^{k} \hat{b}_{k} \operatorname{cov}(X k, \ln y) / \sigma^{2}(\ln y)=\sigma^{2}(\ln \hat{y}) / \sigma^{2}(\ln y)=R^{2}
\end{aligned}
$$

The less $\hat{\epsilon}$ in Eq. (4), the larger the explanatory power $\left(R^{2}\right)$.

\section{Results}

How can we explain the high level of household income inequality and wealth inequality in South Korea? Which factors contribute to inequality of income and wealth? Does an individual's occupation explain the inequality of household income? Do demographic factors and family change affect the distribution of household income? How is income inequality associated with wealth inequality? The regression-based inequality decomposition method might be helpful for getting answers to some of those questions. $^{3}$

\footnotetext{
${ }^{3}$ We used ineqrbd, the STATA module, to calculate the regression-based inequality decomposition proposed by Fiorio and Jenkins (2007).
} 
We take two steps to decompose inequality of household income and wealth by each contributing factor. The first step is to specify income functions and wealth functions, respectively, and estimate coefficients of variables in those functions by linear regression analyses. The second step is to estimate the variance of household income explained by the covariance of each independent variable and household income. It is a decomposition of the total explained variance $\left(R^{2}\right)$ into contributions by each independent variable based on Shapley value.

Table 3 reports the results of the regression-based inequality decomposition based on the model that specifies some income functions. The best-fitting models, that is, the model with the highest $R^{2}$ and significant coefficients, are used to estimate the contribution of each variable to the variance of household income and wealth. The residuals refer to the unexplained variance of inequality of household income by the model, 1$R^{2}$. The number indicates the proportion of the variance of household income explained by each variable. For example, the sex of household head explains $2.0593 \%$ of the total variance of household income, whereas education explains $4.8322 \%$ of it. Those are relatively low because household dynamics are different from individual earnings in the labor market.

In Table 3, the occupation of the household head is the largest contributor to the variance of household income. ${ }^{4}$ It explains $31.0587 \%$ of the explained variance of household income. Individual characteristics such as sex and age do not contribute to the variance of household income that much, while education exerts modest influence on it by $7.9632 \%$. Household wealth is the second largest contributor to the variance of household income by $27.8768 \%$. Family size plays a significant role in household income inequality. It explains $22.0512 \%$ of the explained variance of household income.

Model 2 in Table 3 provides a more parsimonious model in which occupation and industry of household head are excluded, and only the employment status of the household head is included. Employment status consists of regular employment, non-regular employment, employing other employees, self-employment without employees and atypical workers, and non-working person. Model 2 fits the data as good as the model 1 with the almost same explained variance, $R^{2} 0.606816$ vs. 60.0000 . The impact of employment status on household income inequality comes from inequality between

Table 3 Household income inequality decomposed through multivariate variables (\%)

\begin{tabular}{lllll}
\hline & Model 1 & & Model 2 & \\
\hline Sex & 2.0593 & 3.3936 & 1.5893 & 2.6488 \\
Age + Age-squared & 3.4320 & 5.6558 & 0.2023 & 0.3372 \\
Education & 4.8322 & 7.9632 & 5.8808 & 9.8001 \\
Employment status & 2.7471 & 4.5271 & 13.1029 & 21.8382 \\
Occupation & 18.8469 & 31.0587 & - & - \\
Industry & 4.9104 & 8.0921 & - & - \\
Wealth & 16.9161 & 27.8768 & 17.5451 & 29.2418 \\
Family size & 13.3810 & 22.0512 & 16.5935 & 27.6558 \\
Residuals & 39.3184 & - & 39.9171 & - \\
$R^{2}$ & 100.00 & 60.6816 & 100.00 & 60.0000 \\
Total & 100.00 & 100.00 & 100.00 & 100.00 \\
\hline
\end{tabular}


working persons and non-working persons. Both occupation and employment status include non-working persons, who increased household income inequality substantially.

Table 4 displays the contribution of each variable to the total variance of wealth, following the same equation for household income and a modified equation dropping occupation and industry and adding loans. Model 1 in Table 4 includes household income in the independent variables to explain wealth. Unlike the decomposition of income inequality, individual characteristics and work-related variables do not display large impact on wealth inequality. Household income and education explain more than $60 \%$ of wealth inequality. Model 2 introduces loans and drops occupation and industry in the wealth equation to explain wealth inequality. While debt might be a survival resource for the poor, it can be a resource for the middle class and the rich for new investment. Thus, loans can be a leverage for enhancing wealth for the rich. As Fig. 3 illustrates, the high-income groups are more likely to utilize loans than low-income groups. The high-income groups have more chance to eleviate their wealth and promote their life chances through the financial markets. We observe the polarization of the financial markets in favor of the wealthy class.

Significant contributors to wealth inequality are quite different from those of income inequality. When we apply the same variables in the equations, we find out very different impacts on income and wealth. First of all, human capital variables are very weak in their impact on wealth inequality. Therefore, we include only selected variables that were significantly affecting wealth inequality. The model selected through regression analysis is presented in model 2 in Table 4 in which income and loans explain almost $75 \%$ of inequality of wealth. Loans alone contribute to wealth inequality by $43.9148 \%$, and household income contributes to $32.6228 \%$. Although the accumulation of income for a period could contribute to the growth of wealth, loans seem to be more directly associated with wealth. As housing price has continued to increase in the twenty-first century, the deregulation of financial markets and severe competition among financial institution has promoted the mortgage loans to the middle class. As the real estate bubble grows for a while, wealth inequality will continue to increase as well.

The above results display two things. First, the dynamics of income and wealth are different from each other. While income inequality and wealth inequality are significant dimensions of economic inequality, the mechanisms of the formation of income and wealth are very different. Income is an outcome of economic activities as well as profits from the capital, whereas loans are a financial resource based on income and wealth. Second, the credit system as a core institution in the financialized economy functions for the social group, which already enjoys the advantage. That exacerbates income distribution and economic inequality.

\footnotetext{
${ }^{4}$ The contribution of categorical variables to inequality is based on dummy coding. For example, the occupation in this data has 11 categories; 9 occupational categories, one non-working, and soldiers. Managerial occupation is a reference (base) category. The contribution of each categorical variable to inequality is the sum of the contribution by each category. It will generate the same result though we change the reference category for any reason.
} 
Table 4 Wealth inequality decomposed through multivariate variables (\%)

\begin{tabular}{|c|c|c|c|c|}
\hline \multirow[b]{2}{*}{ Sex } & \multicolumn{2}{|l|}{ Model 1} & \multicolumn{2}{|l|}{ Model 2} \\
\hline & 0.7435 & 1.3959 & 0.8202 & .6488 \\
\hline Age + Age-squared & -1.2328 & -0.0216 & 0.8311 & 0.3372 \\
\hline Education & 6.9042 & 12.1185 & 3.5798 & 6.9621 \\
\hline Employment status & 1.1242 & 1.9732 & 4.0311 & 7.8399 \\
\hline Occupation & 0.3763 & 0.6605 & - & - \\
\hline Industry & 4.8705 & 8.5489 & - & - \\
\hline Income & 24.5113 & 48.9305 & 16.7739 & 32.6228 \\
\hline Loans & - & - & 22.5800 & 43.9148 \\
\hline Family size & 5.9041 & 10.3631 & 3.9844 & 7.7490 \\
\hline Residuals & 56.9722 & - & 48.5823 & - \\
\hline$R^{2}$ & 100.00 & 43.0278 & 100.00 & 51.4177 \\
\hline Total & 100.00 & 100.00 & 100.00 & 100.00 \\
\hline
\end{tabular}

\section{Conclusion}

Analyzing the SHFLC data that linked the survey data with administrative data in South Korea, this paper attempts to explore income inequality and wealth inequality and their reciprocal relationship mediated by financial behavior. While income inequality and wealth inequality are the two major dimensions of social inequality, sociologists did not pay much attention to income inequality and wealth inequality. Rather, individual social mobility based on occupation has been a core research topic among sociologists in social stratification. Wage inequality has been a focal arena among sociologists in the research on the labor market and gender gap. Therefore, sociologists have stopped at the individual's occupation, fall short of a comprehensive understanding of the rising inequality of income and wealth since the late twentieth century.

The analysis of inequality of income and wealth in this paper reveals at least five findings. First, the linked data combining the survey data with administrative data shows higher income inequality than the survey data. The SHFLC data provide more accurate information about household income, which was registered information around

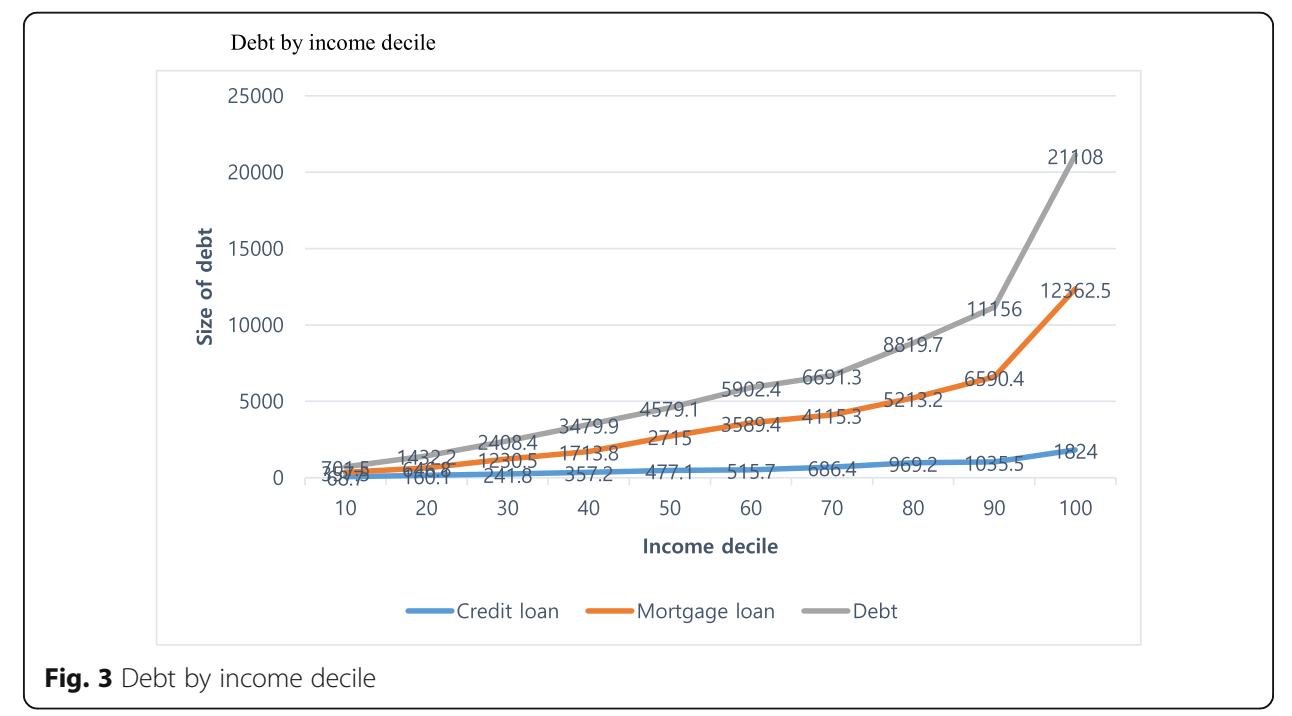


different governmental agencies. It provides a new possibility for social scientists to investigate income inequality.

Second, wealth inequality is much more severe than income inequality in South Korea. Almost all indicators of inequality, such as the Gini coefficient, the top 10\% share, and p90/p10, display that wealth is much more concentrated into the top $10 \%$ than income. While ordinary people perceive wealth inequality as a core of economic inequality, sociologists did not pay much attention to it for various reasons.

Third, the joint distribution of income and wealth shows the highly bi-polarized distribution in which the pole with the highest $5 \%$ of income and the highest $5 \%$ of wealth shows the highest density, indicating the concentration of both income and wealth at the top $5 \%$ of the rich household. The opposite pole with the lowest $5 \%$ income and the lowest $5 \%$ wealth shows the second-highest density, revealing the concentration of poverty in the lowest $5 \%$ of the household.

Fourth, the dynamics of income and income inequality are different from the dynamics of wealth and wealth inequality. Household income has been affected by occupation and family size as well as work-related variables, such as employment status and occupation. Unlike the expectation of researchers on occupation, the effect of occupation on income inequality is not based on the technical division of labor but the division between working and non-working population. Thus, employment status rather than occupation provides a better fitting model with fewer variables. Wealth has been most affected by household income and loans in South Korea. It indicates that income directly affects wealth, and loans mediate the formation of wealth. As the housing market bubble has grown for the last decade, loans and credit systems play a significant role in aggravating wealth inequality.

Fifth, the positive feedback loops are working between income and wealth through capital income and credit systems. The multiplicative effect of the feedback loops has contributed to the concentration of income and wealth on the top 5 or $10 \%$ in recent years, widening the gap further between the rich and the poor. As wealth is the most significant factor of income inequality and income is the second most important factor of wealth inequality, income inequality tends to increase further with the rise of the real estate price in recent years in South Korea.

There are some limitations to this paper. One is the problem of the representativeness of the survey data. Although the size of the Survey of the Household Finance and Living Conditions is much larger than the previous survey data, the wealthy families reported in the media are not sufficiently included in the data. Furthermore, the extremely poor are also excluded due to the limitation of accessibility to them. Thus, the underestimation of income and wealth inequality may be possible. While the linked data was used, at least the problem of under-representation and inaccessibility remains unabated. In particular, underrepresentation of the super-rich may result in a much lower estimation of income inequality and wealth inequality.

Another limitation is the lack of information about an inheritance from parents to children. The survey data used in this research cannot capture the exact amount of inheritance because the information entirely depends on respondents' answers to survey questionnaires. Information about inheritance may be a piece of sensitive information that cannot be revealed by survey interviewers. In addition, most of the heirs of property do not pay inheritance tax because the tax bracket is too high, and most of the 
heirs are exempted from taxation. Nevertheless, inheritance has been an essential part of wealth formation of the people, and wealth transmission over a generation has been an institutionalized pathway of the rich to maintain their socioeconomic positions across all societies. We need different data, such as the fully merged administrative data, as so to thoroughly investigate the dynamics of income and wealth inequality.

Abbreviations

OED: Origin-Education-Destination; SHFLC: The Survey of Household Finances and Living Conditions

\section{Author's contributions}

All works are done by the author alone.

Funding

No funding

\section{Availability of data and materials}

The data used in this paper is a public data accessible to any researchers, if they register to the Statistical Office Korea via the Internet.

\section{Competing interests}

I declare that there is no competing interest.

Received: 5 February 2020 Accepted: 6 July 2020

Published online: 17 September 2020

\section{References}

Acker, Joan. 1973. "Women and social stratification: a case of intellectual sexism," American Journal of Sociology 78(4): 936-945. Alvaredo, Facundo, Lucas Chancel, Thomas Piketty, Immanuel Saez, and Gabriel Zucman. 2018. World inequality report 2018. Berlin: World Inequality Lab.

Atkinson, Tony. 2015. Inequality. Cambridge, Mass.: Harvard University Press.

Breen, Richard and David Muller. 2020. Education and intergenerational social mobility in Europe and the United States, Stanford: Stanford University Press.

Davis, Gerald F., and Suntae Kim. 2015. Financialization of the economy. Annual Review of Sociology 41: 12-211.

Esping-Andersen, Gøsta. 1999. Social foundation of the postindustrial economies. Oxford: Oxford University Press.

Fiorio, Carlo V., and Stephen P. Jenkins, 2007. "INEQRBD: Stata module to calculate regression-based inequality decomposition," Statistical Software Components S456960, Boston College Department of Economics, revised 02 Apr 2010.

Jäntti, Markus, Eva Sierminska, and Philippe Van Kerm. 2013. The joint distribution of income and wealth. In Income inequality: Economic disparities and the middle class in affluent countries, ed. Janet Gornick and Markus Jäntti, 285-311. Stanford: Stanford University Press.

Kalleberg, Arne L. 2000. Nonstandard employment: Part-time, temporary and contract work. Annual Review of Sociology 26 (1): 341-365.

Kenworthy, Lane. 2007. Inequality and sociology. American Behavioral Scientist 50 (5): 584-602.

Kim, Keuntae. 2017. The changing role of employment status in marriage of formation among young Korean adults. Demographic Research 36 (5): 145-172.

Kroll, Luisa and Kerry A. Dolan. 2019. "Billionaire: the richest people in the world," Forbes March 5, 2019

Myles, John. 2003. Where have all the sociologists gone? Explaining economic inequality. The Canadian Journal of Sociology 28 (4): $551-559$.

OECD. 2018. A broken social elevator? How to promote social mobility. Paris: OECD.

OECD. 2019. Employment outlook 2019: The future of work. Paris: OECD.

OECD. 2020. Household debt (http://lps3.www.oecd-ilibrary.org.proxy.cau.ac.kr/economics/household-debt/indicator/english_ f03b6469-en, accessed by January 13, 2020).

Piketty, Thomas. 2013. Capital in the $21^{\text {st }}$ century. Cambridge, Mass.: Harvard University Press.

Piketty, Thomas, and Emmanuel Saez. 2003. Income inequality in the United States, 1913-1998. Quarterly Journal of Economics 118 (1): 1-39.

Savage, Mike. 2016. "Are we seeing a new "inequality paradigm" in social sciences?" (https://blogs.lse.ac.uk/politicsandpolicy/ are-we-seeing-a-new-inequality-paradigm-in-social-science/ accessed by January 10, 2020)

Savage, Mike, and Rogers Burrows. 2007. The coming crisis of empirical sociology. Sociology 41 (5): 885-843.

Sawyer, Malcolm. 2013. What is financialization? International Journal of Political Economy 42 (4): 5-18.

Shin, Kwang-Yeong. 2013. Economic crisis, neoliberal reforms, and the rise of precarious work in South Korea. American Behavioral Scientist 57 (3): 353-355.

Sierminska, Eva, Timothy M. Smeeding, and Serge Allegrezza. 2013. The distribution of asset and debt. In Income inequality: Economic disparity and the middle class in affluent countries, ed. Janet Gornick and Markus Jäntti, 285-311. Stanford: Stanford University Press.

Stiglitz, Joseph. 2012. The price of inequality: How today's divided society endangers our future. New York: W. W. Norton. Therborn, Goran. 2013. The killing fields of inequality. Cambridge: Polity.

\section{Publisher's Note}

Springer Nature remains neutral with regard to jurisdictional claims in published maps and institutional affiliations. 